\title{
Cropping With Slag to Address Soil, Environment, and Food Security
}

\author{
Suvendu Das', Gil Won Kim ${ }^{2}$, Hyun Young Hwang ${ }^{3}$, Pankaj Prakash Verma ${ }^{1}$ and \\ Pil Joo Kim ${ }^{1,3 *}$
}

${ }^{1}$ Institute of Agriculture and Life Sciences, Gyeongsang National University, Jinju, South Korea, ${ }^{2}$ Hawkesbury Institute for the Environment, Western Sydney University, Penrith, NSW, Australia, ${ }^{3}$ Division of Applied Life Science, Gyeongsang National

University, Jinju, South Korea

OPEN ACCESS

Edited by:

Marc Gregory Dumont, University of Southampton, United Kingdom

Reviewed by:

Weiqi Wang,

Fujian Normal University, China Genxing Pan,

Nanjing Agricultural University, China

*Correspondence:

Pil Joo Kim

pjkim@gnu.ac.kr

Specialty section:

This article was submitted to

Terrestrial Microbiology,

a section of the journal

Frontiers in Microbiology

Received: 03 December 2018

Accepted: 27 May 2019

Published: 18 June 2019

Citation:

Das S, Kim GW, Hwang HY,

Verma PP and Kim PJ (2019)

Cropping With Slag to Address Soil,

Environment, and Food Security.

Front. Microbiol. 10:1320.

doi: 10.3389/fmicb.2019.01320
The effective utilization of slag fertilizer in agriculture to neutralize soil acidity, improve crop productivity, mitigate greenhouse gas emissions, and stabilize heavy metals in contaminated soils turns it into a high value added product in sustainable agriculture. These effects could be due to the shift in microbial metabolism and/or modification of microbial habitats. At the system level, soil microorganisms play an integral role in virtually all ecosystem processes. There is a growing interest to reveal the underlying mechanisms of slag-microbe interactions and the contribution of soil biota to ecosystem functioning. In this perspective, we discuss the possible driving mechanisms of slag-microbe interactions in soil and how these slag-microbe interactions can affect crop yield, greenhouse gas emissions, soil carbon sequestration, and heavy metal stabilization in contaminated soils. In addition, we discuss the problems and environmental concerns in using slag in agriculture. Emphasis has been given for further research to validate the proposed mechanisms associated with slag-microbe interactions for increasing soil quality, crop productivity, and mitigating environmental consequences. While evaluating the slag amendment, effects on agriculture and environment, the potential risks, socio-economics, techno-economics, and ethics should be assessed.

Keywords: microbial dynamics, silicate fertilization, slag, greenhouse gas emissions, carbon sequestration

\section{INTRODUCTION}

Over the past decades, with the rapid growth of industrialization, the higher volume of byproducts (slag) generated from iron/steel production draw attention to the need for its recycling in an increasingly efficient way. With the increase in population, the available land to dispose of large amounts of slag in landfill sites is reduced and the disposal cost is becoming increasingly higher. Moreover, the land filled with disposed slag has become an important source of pollution of air, water, and soil, which further adversely affects vegetation and human health (Branca and Colla, 2012). The entry of heavy metals/metalloids into the food chain is a critical issue of current public health (Chand et al., 2015). From the perspective of natural resource conservation, environmental protection, and human health safety measures, recycling 
of slag has drawn the attention of scientists, environmentalists, and policymakers in recent years. The increase of slag recovery and use in different fields of application, such as agriculture, is an imperative way for sustainable development (Ito, 2015).

Slag consists mostly of mixed oxides of elements such as silicon, sulfur, phosphorus, and aluminum, and products formed in their reactions with furnace linings and fluxing substances such as limestone (Yildirim and Prezzi, 2011; Piatak et al., 2015). Since slag is rich in lime $(\mathrm{CaO})$, silicic acid $\left(\mathrm{SiO}_{2}\right)$, phosphoric acid $\left(\mathrm{P}_{2} \mathrm{O}_{5}\right)$, magnesia $(\mathrm{MgO}), \mathrm{Mn}$, and $\mathrm{Fe}$, these properties of the slag can be exploited to make use of fertilizer (Ito, 2015). Notably, steel-making slag and blast furnace slag have been extensively utilized as raw materials for fertilizer production, mostly in Japan, Korea, and China. Fertilizers made of slag are categorized as slag silicate fertilizer, lime fertilizer, slag phosphate fertilizer, and iron matter of special fertilizer (Ito, 2015). In recent years, several studies have revealed that the slag-based fertilizer amendment in agriculture has great promise to improve crop productivity (White et al., 2017; Gwon et al., 2018), alleviate soil acidification (Ning et al., 2016), mitigate greenhouse gas (GHG) emissions (Wang et al., 2015; Gwon et al., 2018), and stabilize heavy metals in contaminated soils (Ning et al., 2016), which turns it into a high value added product for sustainable agriculture. These beneficial effects of slag fertilization largely rely on the changes in soil microbial habitats and microbial activities. In fact, at the system level, soil microorganisms play a vital role in virtually all ecosystem processes and provide ecosystem services crucial for the maintenance of soil quality and productivity (Das et al., 2017). In this perspective, we discuss the driving mechanisms of slag-microbe interactions in soil, and slag-microbe interaction effects on crop yield, greenhouse gas reduction, soil carbon storage, and heavy metal stabilization in contaminated soils. Lastly, we discuss environmental concerns about the use of slag in agriculture and the future perspectives.

\section{DRIVING MECHANISMS OF SLAG-MICROBE INTERACTIONS IN SOIL}

The shift in soil microbial community and activities in response to slag fertilizer amendment may depend on the type of slag fertilizer (e.g., silicate fertilizer, lime fertilizer, slag phosphate fertilizer, and iron matter of special fertilizer), which modify soil properties and soil microbial habitats. With advances in omic techniques, soil microbial communities and communitylevel molecular characteristics have been exploited as early indicators of ecosystem processes for sustainable soil management and agricultural productivity (Shokralla et al., 2012). In recent years, extensive research has been conducted to obtain a mechanistic understanding of the contribution of microbial communities to ecosystem functioning under various agronomic management practices. Unfortunately, few studies have focused specifically on understanding the changes in soil microbial community and function under slag fertilizer amendment in cropping systems. Since the mechanisms of slag-microbe interactions in soil are still not clear, this perspective focuses on the synthesis of several possible mechanisms based on published research. The influence of slag fertilizer on the soil microbiome are diverse and the possible mechanisms of slagmicrobes interactions can be as follows: (1) slag fertilizer supplies nutrients not only to the plant but also to soil microorganisms; (2) slag fertilizer modifies soil microbial habitats by improving soil properties (e.g., increasing soil pH) (Gwon et al., 2018), which is essential for nutrient mobilization and microbial growth; (3) silicate fertilizer increases plant photosynthesis (Detmann et al., 2012) and likely increases belowground carbon allocation through root exudates, which eventually triggers soil microbial proliferation and activities; and (4) steel slag enhances heavy metal immobilization in soil (Ning et al., 2016) and thus reduces their bioavailability and toxicity to microbes. Besides, the slag fertilizer amendment may induce changes in soil enzyme activities that affect soil nutrient mobilization and microbial dynamics. In Figure 1, we show the proposed mechanism of slag-microbe interactions in soil. The proposed mechanisms of slag-microbe interactions need to be experimentally verified and intensive research needs to be conducted to explore the microbial role in soil processes and agricultural productivity. The potential effects of slag on crop plants have been described in the separate subheading and also shown in Figure 2.

\section{SLAG-MICROBE INTERACTION EFFECTS ON CROP YIELD}

Among fertilizers made from slag, the use of silicate fertilizer, particularly in rice cropping systems has been gaining awareness and demand (Meharg and Meharg, 2015). Rice is a high Si accumulating plant. Intensive rice cultivation to meet the growing food demand chronically depletes $\mathrm{Si}$ from soil, thus degrades soil quality and decreases the crop yield (Branca and Colla, 2012). This necessitates silicate fertilizer amendment in rice cropping systems for sustainable rice cultivation. Studies have indicated an increase $(0.16-47.2 \%)$ in rice grain yield in lowland rice fields following the addition of slag-based silica fertilizer (Supplementary Table S1). The increase in grain yield, however, mostly depends on slag type, application rate, soil type, and agronomic management. Ali et al. (2009a) reported that the silicate fertilizer amendment in no-tillage submerged paddies could improve the crop yield up to $47.2 \%$. Wang et al. (2015) suggested that the silicate fertilization is not significantly effective in improving the rice yield. Higher grain yields in response to silicate fertilization could be attributed to the fact that Si preferentially deposits in the epidermal cell wall and increases physical strength of leaves and leaf-sheaths and help plants to sustain yield by counteracting various biotic and abiotic stresses and increasing plant biomass (Luyckx et al., 2017). Besides silicate fertilizer, lime fertilizer has been widely used in acidic soil to neutralize the soil, which helps plants to protect themselves against soil pathogens. In addition, $\mathrm{Ca}$ content in slag fertilizer makes the roots strong and promotes the absorption of $\mathrm{K}$, which is important for plant growth. Slag phosphate fertilizer has been used to provide adequate 


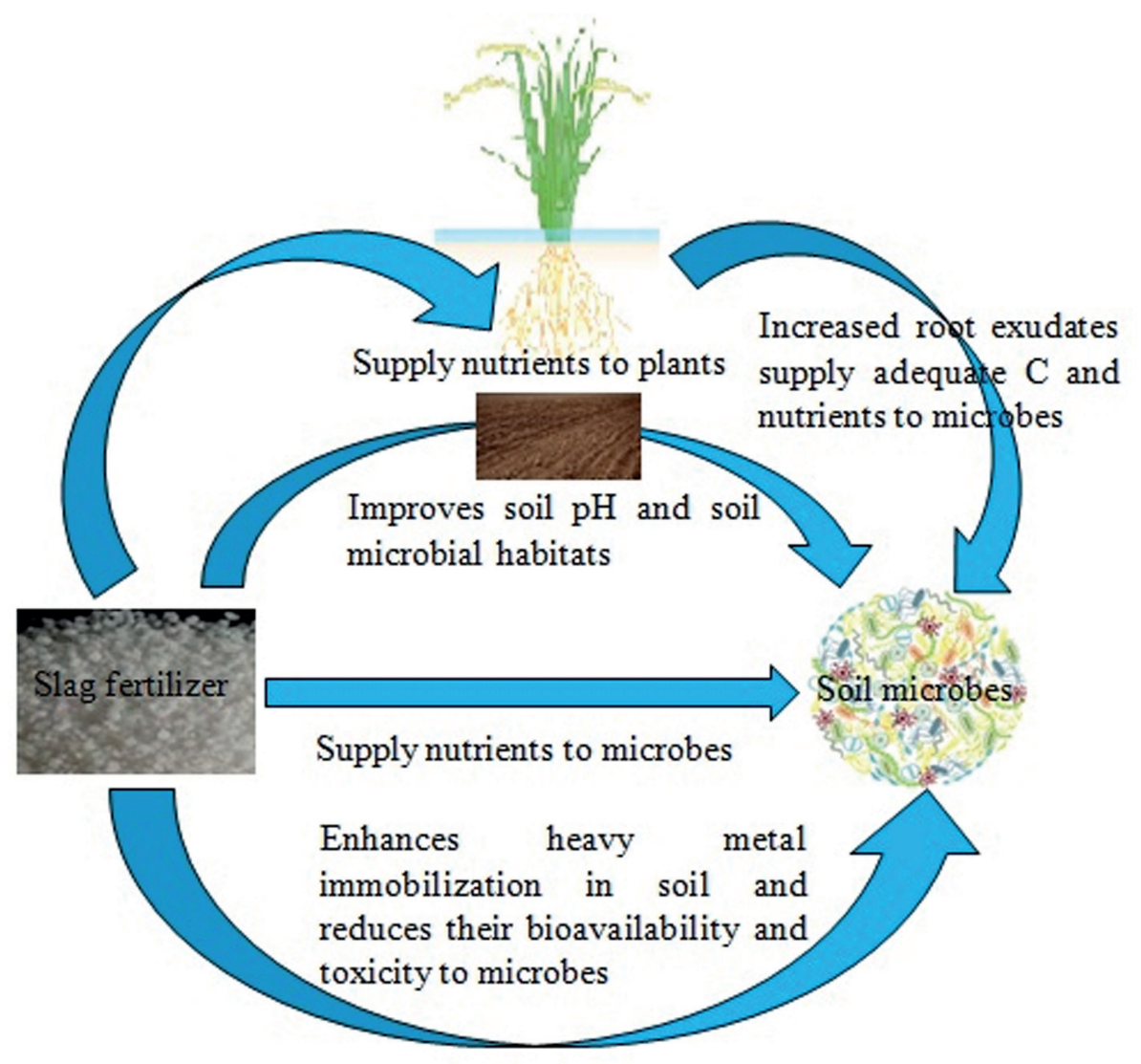

FIGURE 1 | The proposed mechanism of slag-microbe interactions in soil.

phosphorus to the plant, which improves plant growth and fruiting. Likewise, the iron matter of special fertilizer has been used to mitigate the toxicity of heavy metals in soil as well as in the plant. Noteworthy, the increased yield under slag fertilization is largely regulated by microbial decomposition of organic matter and nutrient mobilization. It can be postulated that slag fertilizer amendment not only increases soil nutrients per se, but also enriches soil microorganisms that have a beneficial role in nutrient mobilization (e.g., carbon and nitrogen mineralization, phosphorus solubilization, nitrogen fixation, etc.). Identification and elucidation of functional roles of keystone soil microbes that sustain plant health and productivity under slag fertilization could provide a technological breakthrough for a sustainable use of slag in agricultural productivity.

\section{SLAG-MICROBE INTERACTION EFFECTS ON GREENHOUSE GAS EMISSIONS}

Agriculture significantly contributes to the emission of methane $\left(\mathrm{CH}_{4}\right)$ and nitrous oxide $\left(\mathrm{N}_{2} \mathrm{O}\right)$, which are two of the most important greenhouse gases responsible for global warming (Das and Adhya, 2014). Methane emission from soils is regulated

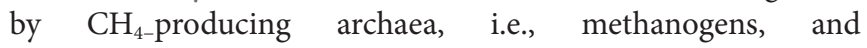

$\mathrm{CH}_{4}$-consuming bacteria, i.e., methanotrophs, while $\mathrm{N}_{2} \mathrm{O}$ emission is mostly regulated by nitrifying and denitrifying bacteria (Singh et al., 2010). Soil amendment that reduces methanogen abundance and activity, and/or increases methanotroph abundance and activity could be effective to mitigate $\mathrm{CH}_{4}$ emissions from the soil. Slag fertilizers, in particular, iron/steel slag fertilizers are rich in iron. Iron acts as an alternative electron acceptor in anoxic soil and its application decreases $\mathrm{CH}_{4}$ emissions by stimulating iron-reducing bacteria at the expense of methanogens (Gwon et al., 2018). Ali et al. (2009b) showed that $4 \mathrm{~mol}$ of $\mathrm{Fe}^{3+}$ prevent the generation of $1 \mathrm{~mol}$ of $\mathrm{CH}_{4}$. Moreover, silicate fertilizer amendment can increase root biomass and $\mathrm{O}_{2}$ transport from the plant to root by enlarging arenchyma gas channels (Liang et al., 2007), which in turn suppresses $\mathrm{CH}_{4}$ production and stimulates $\mathrm{CH}_{4}$ oxidation. Studies conducted in Korea, Japan, China, Indonesia, and Bangladesh indicated the potential of slag fertilizer amendment to decrease $\mathrm{CH}_{4}$ emissions by 0.6-56.0\% from lowland rice paddies (Supplementary Table S1). The extent of $\mathrm{CH}_{4}$ emissions reduction depended on the slag fertilizer type, rate of application, soil type, and agronomic practices (Supplementary Table S1). Wang et al. (2018a) showed that the application of slag fertilizer $\left(8 \mathrm{Mg} \mathrm{ha}^{-1}\right)$ with biochar $\left(8 \mathrm{Mg} \mathrm{ha}^{-1}\right.$ ) reduced $\mathrm{CH}_{4}$ emission up to $38.6 \%$ in early rice in China; however, Lee et al. (2012) reported that the silicate fertilization is not effective in reducing $\mathrm{CH}_{4}$ emissions in green 


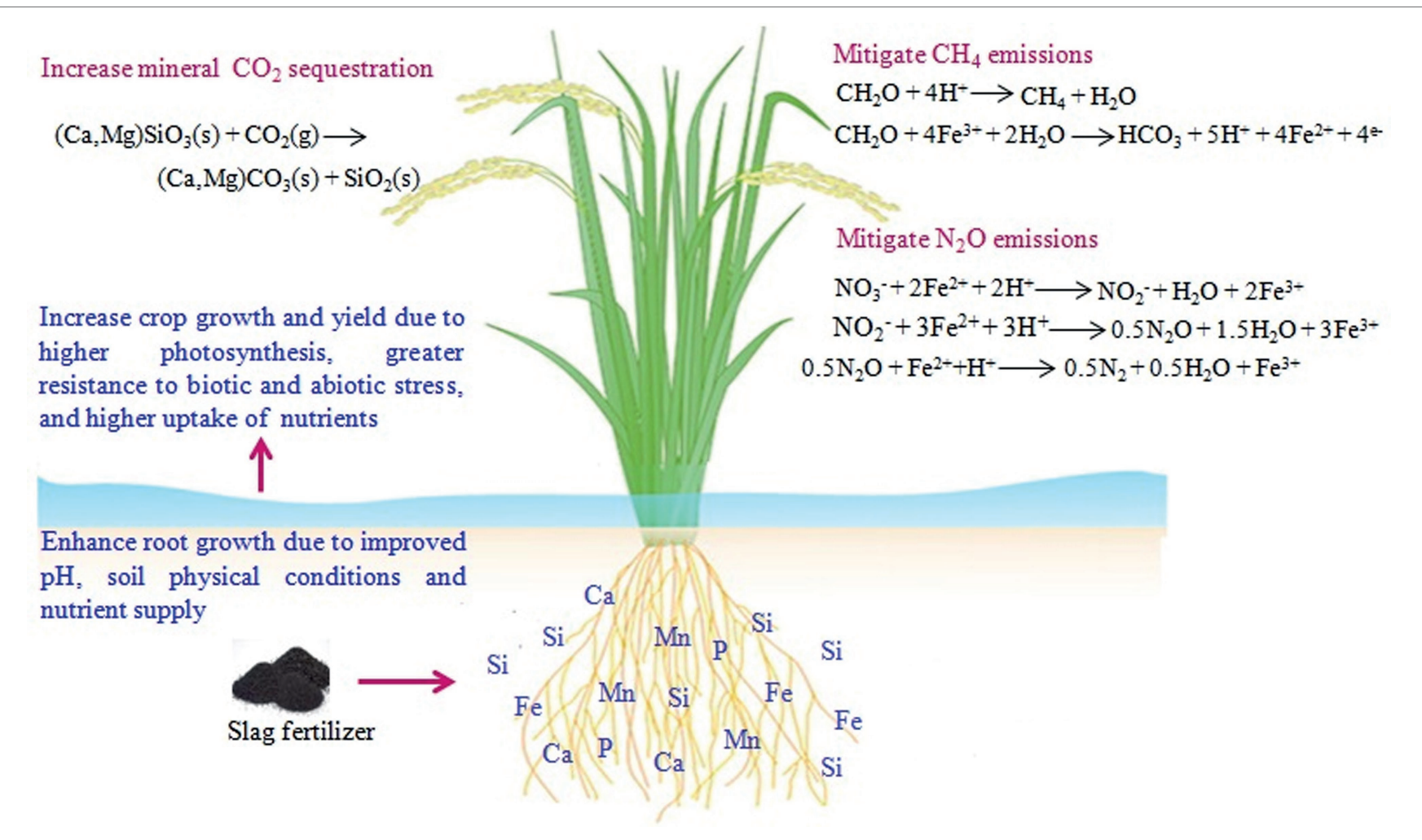

FIGURE 2 | Summary of potential effects of slag on crop plants.

manure amended paddy soils probably due to the enhanced decomposition of added organic matter by the silicate liming effect. Elucidation of methanogen and methanotroph diversity and their functional changes in response to slag fertilizer amendment will improve our mechanistic understanding of $\mathrm{CH}_{4}$ dynamics in relation to slag fertilization.

Unlike $\mathrm{CH}_{4}$ emissions, the slag fertilizer effects on $\mathrm{N}_{2} \mathrm{O}$ emissions from rice cropping systems are contradictory. Some studies suggest slag fertilizer decreases $\mathrm{N}_{2} \mathrm{O}$ emissions (Susilawati et al., 2015; Wang et al., 2015), while other studies suggest slag fertilizer increases $\mathrm{N}_{2} \mathrm{O}$ emissions (Huang et al., 2009; Liu et al., 2012). Wang et al. (2015) indicated that a $99 \%$ reduction in $\mathrm{N}_{2} \mathrm{O}$ emissions could be achieved in an intermittent irrigated rice paddy using silicate fertilizer at the rate of $8 \mathrm{Mg} \mathrm{ha}^{-1}$. The decrease in $\mathrm{N}_{2} \mathrm{O}$ emissions have been attributed to lower $\mathrm{N}$ availability and higher $\mathrm{Fe}$ availability with $\mathrm{Si}$ fertilization. Iron oxidation coupled to denitrification can occur in anoxic soils, which can lead to $\mathrm{N}_{2} \mathrm{O}$ production (Melton et al., 2014); however, under conditions where $\mathrm{Fe}$ is highly available, the electrons donated by $\mathrm{Fe}(\mathrm{II})$ exceed the electron demand for $\mathrm{N}_{2} \mathrm{O}$ production, which leads to complete denitrification to $\mathrm{N}_{2}$ and thus a suppression of $\mathrm{N}_{2} \mathrm{O}$ emissions (Wang et al., 2016). Increases in $\mathrm{N}_{2} \mathrm{O}$ emissions with $\mathrm{Si}$ fertilization have been attributed to: (1) Si fertilization acting to lower soil C decomposition, which would alleviate immobilization of fertilizer $\mathrm{N}$ thereby making more mineral $\mathrm{N}$ available to nitrification and denitrification; and (2) Si fertilization improving soil $\mathrm{pH}$ and Eh, which are two factors important to $\mathrm{N}_{2} \mathrm{O}$ emissions (Huang et al., 2009; Liu et al., 2012). In a recent study, Song et al. (2017) reported that the silicate fertilizer amendment significantly decreased denitrification potential and nirS and nirK gene abundance in paddy soils. Owing to the contradictory results, the mechanism underlying $\mathrm{N}_{2} \mathrm{O}$ emissions and changes in the genetic potential of nitrifying and denitrifying bacteria under slag fertilization needs further investigation.

\section{SLAG-MICROBE INTERACTION EFFECTS ON SOIL CARBON STORAGE}

Carbon dioxide sequestration in soils is well recognized as an avenue to mitigate climate change. Mineral carbonation of $\mathrm{CO}_{2}$ (mineral $\mathrm{CO}_{2}$ sequestration) occurs spontaneously on geological time scales and has a high potential for $\mathrm{CO}_{2}$ sequestration (Oelkers et al., 2008). It typically involves the dissolution of silicate minerals and subsequent precipitation of stable carbonate minerals (e.g., $\mathrm{CaCO}_{3}, \mathrm{MgCO}_{3}$, and $\mathrm{FeCO}_{3}$ ). Mineral carbonation reactions require combining $\mathrm{CO}_{2}$ with metals to form stable carbonate minerals. With few exceptions, the required metals are divalent cations, including $\mathrm{Ca}^{2+}, \mathrm{Mg}^{2+}$, and $\mathrm{Fe}^{2+}$, and the most abundant cation source are silicate minerals. Although mineral carbonation is thermodynamically favorable, it proceeds very slowly (Oelkers et al., 2008). Research is going on worldwide to enhance mineral weathering processes and to accelerate mineral carbonation reactions (Salek et al., 2013). There are 
only few reports concerning the effects of the slag fertilizer amendment on carbon sequestration in cropping systems. Wang et al. (2018) reported that the addition of steel slag and biochar in subtropical paddy fields could decrease active SOC pools and enhance soil $\mathrm{C}$ sequestration only in the early crop, but not the late crop. Since slag fertilizers are a rich source of silicon minerals and alkaline in nature, their application in agricultural soil may potentially increase soil carbon sequestration. The use of slag fertilizer instead of agricultural lime (limestone) to increase soil $\mathrm{pH}$ would eliminate the dissolution of lime as an important source of agricultural $\mathrm{CO}_{2}$ emissions. It is well recognized that the enzyme carbonic anhydrase (CA) participates in silicate weathering and carbonate formation and thus plays an important role in the biomemetic $\mathrm{CO}_{2}$ sequestration (Bose and Satyanarayana, 2017). Bio-inoculation of bacteria possessing CA activity in slag fertilized agricultural systems could accelerate silicate weathering and enhance $\mathrm{CO}_{2}$ sequestration. Likewise, the introduction of plant growth promoting bacteria possessing CA activity in agriculture could have the dual benefit of increased crop yield and $\mathrm{CO}_{2}$ sequestration. In a recent review it is postulated that farming with rock could have a great promise in sequestering carbon in soils (Beerling et al., 2018). There is an urgent need to evaluate the fate of soil carbon and carbon sequestration potential of slag fertilizer in field conditions.

\section{SLAG-MICROBE INTERACTION EFFECTS ON HEAVY METAL STABILIZATION IN CONTAMINATED SOILS}

The stabilization technique aims at reducing heavy metal and metalloid (e.g., As, Cr, Cu, Pb, Cd, and $\mathrm{Zn}$ ) bioavailability in contaminated soil. The technique is based on amendments to change the soil physicochemical properties through adsorption, precipitation, ion-exchange techniques, redox potential technology, and $\mathrm{pH}$ control technology that change the existing forms and speciation of heavy metals/metalloids and thus, reduce their toxicity (Mosa et al., 2016). There are several examples, as follows: as can be stabilized by sorption on Fe oxyhydroxide and also by the formation of amorphous Fe(III) arsenates; $\mathrm{Cr}$ can be stabilized by the reduction from more mobile and toxic $\mathrm{Cr}(\mathrm{VI})$ to less toxic and stable $\mathrm{Cr}$ (III); $\mathrm{Cu}$ can be stabilized by precipitation of $\mathrm{Cu}$ carbonates and oxyhydroxides, iron exchange and formation of ternary cationanion complexes on the surface of $\mathrm{Fe}$ and $\mathrm{Al}$ oxyhydroxides; and $\mathrm{Pb}$ and $\mathrm{Zn}$ can be immobilized by phosphorus amendments (Branca and Colla, 2012). The slag fertilizer amendment markedly affects the soil solution composition through acid-base, precipitation, and sorption reactions. Owing to its suitable chemical and mineralogical properties, slag fertilizer has been used as a stabilizing agent to minimize metal and metalloid contamination in soil (Ning et al., 2016). Moreover, the adequate Si supply through slag silicate fertilizer amendment causes competitive inhibition of As(III) uptake by crop plants (Meharg and Meharg, 2015). The effects of slag fertilizer amendment on the biogeochemical cycling of soil elements that are regulated by soil microbes need to be investigated. A combination of slag fertilizer and microbial remediation strategies could be proposed for effective remediation of soil contaminants.

\section{ENVIRONMENTAL CONCERNS ABOUT THE USE OF SLAG IN AGRICULTURE}

The main concerns regarding the use of slag in agriculture are the potential for heavy metal accumulation in soil and the risks related to liming of soil (Chand et al., 2015). Slags contain traces of heavy metals, but the concentrations of heavy metals might not be enough to pose environmental risks (Gwon et al., 2018); however, it is believed that the long-term application of slag fertilizer in agriculture may accumulate heavy metals/metalloids in soil and may cause health risks. Several studies reveal that metal contamination in soil and metal uptake by plants are not adversely affected by short-term slag fertilizer amendment in cropping systems (Ali et al., 2008, Gwon et al., 2018). In addition, long-term experiments in Germany showed that steel slag fertilizer amendment did not increase bio-available $\mathrm{Cr}$ content in soil and Cr uptake by plants (Hiltunen and Hiltunen, 2004). Kuhn et al. (2006), however, revealed that the long-term application of converter slag significantly increased $\mathrm{Cr}$ and $\mathrm{V}$ contents in the cultivated layer of soil. For a better understanding of the long-term effects of the slag fertilizer amendment in agriculture, further research under diverse soil types and agronomic management practices need to be carried out. Due to the high reactivity of $\mathrm{CaO}$ and $\mathrm{MgO}$ and high $\mathrm{pH}$ (i.e., 12.5) of $\mathrm{Ca}(\mathrm{OH})_{2}$, repeated application of slag may make the soil excessively alkaline, which may decrease the bioavailability and uptake of macronutrients such as $\mathrm{P}$ and micronutrients such as $\mathrm{Fe}, \mathrm{Cu}$, and $\mathrm{Zn}$ by the plant and likely hinder plant growth and productivity (Chand et al., 2015). Another demerit of slag fertilizer is that it contains small proportions of $\mathrm{N}$ and $\mathrm{K}$, and $\mathrm{P}$ (in some slag fertilizer), which are essential nutrients for plant growth. Therefore, slag fertilizer should be applied together with a chemical fertilizer that contains adequate amounts of $\mathrm{N}, \mathrm{P}$, and $\mathrm{K}$.

\section{CONCLUSIONS AND FUTURE DIRECTIONS}

With the rapid increase in steel production, steel industries are under pressure for effective and eco-friendly recycling of slag. While in the past, steel-making processes were exclusively designed for the production of specific quality and quantities of iron and steel, one of today's goals for steel making is to design and develop technologies to produce high-quality slag according to the market requirements. Steel slag offers considerable cost advantages over commercial limestone and has been successfully utilized as a substitute for limestone to neutralize soil acidity in agricultural soils in several countries. Owing to its high Si content, the use of slag as silicate fertilizer is gaining demand. The term "slag" is used in the specifications of slag 
silicate fertilizer and slag phosphate fertilizer in the Fertilizer Control Law. The slag can be mixed with livestock wastes to make compost, so that both slag and livestock waste can be effectively utilized in agriculture. However, to secure the reliability of the slag as fertilizer, it is quite necessary to conform to the regulations on hazardous heavy metals provided by the Fertilizer Control Law and the soil environmental standards provided by the Basic Law for Environmental Pollution Control.

Understanding the effects of slag fertilizer on soil microbial communities and functions is essential to address some critical agro-environmental issues, such as whether the slag fertilizer amendment would be useful to increase crop productivity, reduce GHG emissions, increase soil carbon sequestration, and stabilize heavy metals in contaminated soils. The recent advances in omic techniques, e.g., highthroughput sequencing, metatranscriptomic analysis, and DNA/RNA-based stable isotope probing (SIP) will no doubt be imperative to uncover the hidden dimensions of slagmicrobe interactions in ecosystem functioning.

\section{REFERENCES}

Ali, M. A., Lee, C. H., Kim, S. Y., and Kim, P. J. (2009b). Effect of industrial by-products containing electron acceptors on mitigating methane emission during rice cultivation. Waste Manag. 29, 2759-2764. doi: 10.1016/j.wasman. 2009.05.018

Ali, M. A., Lee, C. H., Lee, Y. B., and Kim, P. J. (2009a). Silicate fertilization in no-tillage rice farming for mitigation of methane emission and increasing rice productivity. Agric. Ecosyst. Environ. 132, 16-22. doi: 10.1016/j.agee. 2009.02.014

Ali, M. A., Oh, J. H., and Kim, P. J. (2008). Evaluation of silicate iron slag amendment on reducing methane emission from flood water rice farming. Agric. Ecosyst. Environ. 128, 21-26. doi: 10.1016/j.agee.2008.04.014

Beerling, D. J., Leake, J. R., Long, S. P., Scholes, J. D., Ton, J., Nelson, P. N., et al. (2018). Farming with crops and rocks to address global climate, food and soil security. Nat. Plants 4, 138-147. doi: 10.1038/s41477-018-0108-y

Bose, H., and Satyanarayana, T. (2017). Microbial carbonic anhydrases in biomimetic carbon sequestration for mitigating global warming: prospects and perspectives. Front. Microbiol. 8:1615. doi: 10.3389/fmicb.2017.01615

Branca, T. A., and Colla, V. (2012). "Possible uses of steelmaking slag in agriculture: an overview" in Material recycling - Trends and perspectives. ed. D. Achilias (InTech). ISBN: 978-953-51-0327-1. http://cdn.intechopen.com/pdfs/32571/ InTech-Possible_uses_of_steelmaking_slag_in_agriculture_an_overview.pdf

Chand, S., Paul, B., and Kumar, M. (2015). An overview of use of LinzDonawitz (LD) steel slag in agriculture. Curr. World Environ. 10, 975-984. doi: 10.12944/CWE.10.3.29

Das, S., and Adhya, T. K. (2014). Effect of combine application of organic manure and inorganic fertilizer on methane and nitrous oxide emissions from a tropical flooded soil planted to rice. Geoderma 213, 185-192. doi: 10.1016/j.geoderma.2013.08.011

Das, S., Jeong, S. T., Das, S., and Kim, P. J. (2017). Composted cattle manure increases microbial activity and soil fertility more than composted swine manure in a submerged rice paddy. Front. Microb. 8:1702. doi: 10.3389/ fmicb.2017.01702

Detmann, K. C., Araujo, W. L., Martins, S. C. V., Sanglard, L. M. V. P., Reis Josimar, V., Detmann, E., et al. (2012). Silicon nutrition increases grain yield, which, in turn, exerts a feed-forward stimulation of photosynthetic rates via enhanced mesophyll conductance and alters primary metabolism in rice. New Phytol. 196, 752-762. doi: 10.1111/j.1469-8137.2012.04299.x

Gwon, H. S., Khan, M. I., Alam, M. A., Das, S., and Kim, P. J. (2018). Environmental risk assessment of steel-making slags and the potential use of LD slag in mitigating methane emissions and the grain arsenic level in rice (Oryza sativa L.). J. Haz. Mat. 353, 236-243. doi: 10.1016/j.jhazmat.2018.04.023

\section{AUTHOR CONTRIBUTIONS}

SD wrote the manuscript. All authors contributed to the intellectual input and provided assistance to the manuscript preparation.

\section{FUNDING}

This work was supported by the Basic Science Research Program through the National Research Foundation of Korea (NRF) funded by the Ministry of Education (NRF-2017R1A2B2002239).

\section{SUPPLEMENTARY MATERIAL}

The Supplementary Material for this article can be found online at: https://www.frontiersin.org/articles/10.3389/fmicb.2019.01320/ full\#supplementary-material

Hiltunen, R., and Hiltunen, A. (2004). "Environmental aspects of the utilization of steel industry slags" in Proceedings of VII intenational conference on molten slags, fluxes and salts (Cape Town, South Africa: The South African Institute of Mining and Metallurgy). ISBN: 1-919783-58-X.

Huang, B., Yu, K., and Gambrell, R. P. (2009). Effects of ferric iron reduction and regeneration on nitrous oxide and methane emissions in a rice soil. Chemosphere 74, 481-486. doi: 10.1016/j.chemosphere.2008.10.015

Ito, K. (2015). Steelmaking slag for fertilizer usage. Nippon steel and Sumitomo metal technical report no. 109. Avilable at: http://www.nssmc.com/en/tech/ report/nssmc/pdf/109-23.pdf

Kuhn, M., Spiegel, H., Lopez, A. F., Rex, M., and Erdmann, R. (2006). Sustainable agriculture using blast furnace and steel slags as liming agents, European Commission. (Luxembourg: International).

Lee, C. H., Kim, S. Y., Villamil, M. B., Pramanik, P., Hong, C. O., and Kim, P. J. (2012). Different response of silicate fertilizer having electron acceptors on methane emission in rice paddy soil under green manuring. Biol. Fertil. Soils 48, 435-442. doi: 10.1007/s00374-011-0637-2

Liang, Y., Sun, W., Zhu, Y. G., and Christie, P. (2007). Mechanisms of siliconmediated alleviation of abiotic stresses in higher plants: a review. Environ. Pollut. 147, 422-428. doi: 10.1016/j.envpol.2006.06.008

Liu, S., Zhang, L., Liu, Q., and Zou, J. (2012). Fe(III) fertilization mitigating net global warming potential and greenhouse gas intensity in paddy ricewheat rotation systems in China. Environ. Pollut. 164, 73-80. doi: 10.1016/j. envpol.2012.01.029

Luyckx, M., Hausman, J. F., Lutts, S., and Guerriero, G. (2017). Silicon and plants: current knowledge and technological perspectives. Front. Plant Sci. 8:411. doi: $10.3389 /$ fpls.2017.00411

Meharg, C., and Meharg, A. A. (2015). Silicon, the silver bullet for mitigating biotic and abiotic stress, and improving grain quality, in rice? Environ. Exp. Bot. 120, 8-17. doi: 10.1016/j.envexpbot.2015.07.001

Melton, E. D., Swanner, E. D., Behrens, S., Schmidt, C., and Kappler, A. (2014). The interplay of microbially mediated and abiotic reactions in the biogeochemical Fe cycle. Nat. Rev. Microbiol. 12, 797-808. doi: 10.1038/ nrmicro3347

Mosa, K. A., Saadoun, I., Kumar, K., Helmy, M., and Dhankher, O. P. (2016). Potential biotechnological strategies for the cleanup of heavy metals and metalloids. Front. Plant Sci. 7:303. doi: 10.3389/fpls.2016.00303

Ning, D., Liang, Y., Liu, Z., Xiao, J., and Duan, A. (2016). Impacts of steelslag-based silicate fertilizer on soil acidity and silicon availability and metalsimmobilization in a paddy soil. PLoS One 11, 1-15. doi: 10.1371/journal. pone.0168163

Oelkers, E. H., Gislason, S. R., and Matter, J. (2008). Mineral carbonation of CO2. Elements 4, 333-337. doi: 10.2113/gselements.4.5.333 
Piatak, N. M., Parsons, M. B., and Seal, R. R. II (2015). Characteristics and environmental aspects of slag: a review. Appl. Geochem. 57, 236-266. doi: 10.1016/j.apgeochem.2014.04.009

Salek, S. S., Kleerebezem, R., Jonkers, H. M., Witkamp, G., and van Loosdrecht, M. C. M. (2013). Mineral $\mathrm{CO}_{2}$ sequestration by environmental biotechnological processes. Trends Biotechnol. 31, 139-146. doi: 10.1016/j. tibtech.2013.01.005

Shokralla, S., Spall, J. L., Gibson, J. F., and Hajibabaei, M. (2012). Next-generation sequencing technologies for environmental DNA research. Mol. Ecol. 21, 1794-1805. doi: 10.1111/j.1365-294X.2012.05538.x

Singh, B. K., Bardgett, R. D., Smith, P., and Reay, D. S. (2010). Microorganisms and climate change: terrestrial feedbacks and mitigation options. Nat. Rev. Microbiol. 8, 779-790. doi: 10.1038/nrmicro2439

Song, A., Fan, F., Yin, C., Wen, S., Zhang, Y., Fan, X., et al. (2017). The effects of silicon fertilizer on denitrification potential and associated genes abundance in paddy soil. Biol. Fertil. Soils 53, 627-638. doi: 10.1007/s00374-017-1206-0

Susilawati, H. L., Setyanto, P., Makarim, A. K., Ariani, M., Ito, K., and Inubushi, K. (2015). Effects of steel slag applications on $\mathrm{CH}_{4}, \mathrm{~N}_{2} \mathrm{O}$ and the yields of Indonesian rice fields: a case study during two consecutive rice-growing seasons at two sites. Soil Sci. Plant Nut. 61, 704-718. doi: 10.1080/ 00380768.2015.1041861

Wang, M., Hu, R., Zhao, J., Kuzyakov, Y., and Liu, S. (2016). Iron oxidation affects nitrous oxide emissions via donating electrons to denitrification in paddy soils. Geoderma 271, 173-180. doi: 10.1016/j.geoderma.2016.02.022
Wang, W., Lai, D., Abid, A., Neogi, S., Xu, X., and Wang, C. (2018). Effects of steel slag and biochar incorporation on active soil organic carbon pools in a subtropical paddy field. Agronomy 8, 1-17. doi: 10.3390/agronomy8080135

Wang, W., Sardan, J., Lai, D., Wang, C., Zeng, C., Tong, C., et al. (2015). Effects of steel slag application on greenhouse gas emissions and crop yield over multiple growing seasons in a subtropical paddy field in China. Field Crops Res. 171, 146-156. doi: 10.1016/j.fcr.2014.10.014

White, B., Tubana, B. S., Babu, T. Jr., Mascagni, H., Agostinho, F., Datnoff, L. E., et al. (2017). Effect of silicate slag application on wheat grown under two nitrogen rates. Plants 6, 1-14. doi: 10.3390/plants6040047

Yildirim, I. Z., and Prezzi, M. (2011). Chemical, mineralogical, and morphological properties of steel slag. Adv. Civil Eng. 463638, 1-13. doi: 10.1155/2011/463638

Conflict of Interest Statement: The authors declare that the research was conducted in the absence of any commercial or financial relationships that could be construed as a potential conflict of interest.

Copyright (c) 2019 Das, Kim, Hwang, Verma and Kim. This is an open-access article distributed under the terms of the Creative Commons Attribution License (CC BY). The use, distribution or reproduction in other forums is permitted, provided the original author(s) and the copyright owner(s) are credited and that the original publication in this journal is cited, in accordance with accepted academic practice. No use, distribution or reproduction is permitted which does not comply with these terms. 